\title{
DROGA DO PEŁNEJ NORMALIZACJI STOSUNKÓW MIĘDZY PAŃSTWEM I KOŚCIOŁEM ORAZ MIĘDZY PRL A STOLICĄ APOSTOLSKĄ
}

ABSTRACT The article discusses the major steps on the long road to the establishment of full diplomatic relations between Polish People's Republic and the Holy See, as well as efforts to ease the strained internal relations between the government and the Church. The political changes in the 70s led to renewal of the activity of the Common Commission consisting of the Church's and government's representatives. The article outlines the most important achievements of that commission and presents the drafts of legislation. It also presents the events that had finally led to the renewal of diplomatic relations in 1989.

Słowa kluczowe: normalizacja stosunków między PRL i Kościołem, dyplomacja, Komisja Wspólna

Key words: attempts at accommodation of PPR-Church relations, diplomacy, the Common Commission

W latach 70. XX w. Episkopat Polski wielokrotnie postulował zwołanie Komisji Wspólnej przedstawicieli Rządu i Episkopatu dla omówienia problemów z zakresu stosunków między państwem a Kościołem.

20 grudnia $1970 \mathrm{r}$. Władysław Gomułka złożył rezygnację z funkcji I sekretarza KC PZPR. Powstał nowy rząd. 23 grudnia 1970 r. nowy premier Piotr Jaroszewicz oświad- 
czył w Sejmie, że rząd będzie dążył do pełnej normalizacji stosunków między państwem a Kościołem. Powtórzył tę deklarację na posiedzeniu Sejmu w styczniu 1971 r.

Po tej deklaracji bp Bronisław Dąbrowski, sekretarz Episkopatu, odbył kilkugodzinną rozmowę ze Stanisławem Kanią, sekretarzem KC PZPR. Było to 26 stycznia 1971 r. Postulował m.in. odnowienie posiedzeń Komisji Wspólnej, która powinna omówić nie tylko narosłe w ciągu 15 lat problemy w stosunkach państwo-Kościół, ale podjąć także problem nawiązania stosunków dyplomatycznych między PRL a Stolicą Apostolską. Tak bowiem Episkopat rozumiał deklarację o „pełnej normalizacji”. Stanisław Kania minimalizował znaczenie Komisji Wspólnej i w ciągu 10 lat nie odbyło się ani jedno posiedzenie. Rząd chciał wyeliminować Episkopat z rozmów ze Stolicą Apostolską.

Wypadki sierpniowe 1980 r. w Gdańsku, Gdyni, Szczecinie i innych miastach doprowadziły do podpisania sławnych umów społecznych między strajkującymi robotnikami a przedstawicielami rządu. W wyniku tych wydarzeń zmieniła się ekipa rządząca w partii i kierownictwo rządu. 6 września 1980 r. z funkcji I sekretarza KC PZPR ustąpił Edward Gierek.

$\mathrm{Na}$ jego miejsce wybrano Stanisława Kanię, dotąd najbliższego współpracownika Edwarda Gierka. Nowym premierem po ustąpieniu Piotra Jaroszewicza został Józef Pińkowski. Oświadczył on w Sejmie, że wznowiona zostanie działalność Komisji Wspólnej Rządu i Episkopatu. Współprzewodniczącym tej Komisji został wicepremier Kazimierz Barcikowski. 18 września 1980 r. zaprosił on bp. Bronisława Dąbrowskiego oraz mnie, by oznajmić nam wolę rządu do prowadzenia rozmów w Komisji Wspólnej i ustalenie terminu pierwszego posiedzenia na dzień 24 września 1980 r. Ustalono wstępnie skład Komisji Wspólnej ze strony rządowej i kościelnej. Współprzewodniczącym ze strony rządowej był Kazimierz Barcikowski, ze strony kościelnej kard. Franciszek Macharski. Ostateczny skład Komisji Wspólnej miały ustalić sekretariat Episkopatu i Urząd ds. Wyznań do 10 listopada 1980 r. Oba urzędy miały opracować zestaw tematów do omówienia oraz opracować plan pracy Komisji. Ustalono, że Komisja zbierać się będzie przynajmniej co dwa miesiące oraz na wniosek jednej ze stron.

20 listopada 1980 r. Komisja zebrała się w pełnym składzie: wicepremier Kazimierz Barcikowski - współprzewodniczący Komisji, dyrektor Urzędu ds. Wyznań min. Jerzy Kuberski, dyrektor Aleksander Merker z Urzędu ds. Wyznań, Witold Lipski poseł na Sejm z ramienia ZSL. Ze strony kościelnej kard. Franciszek Macharski jako współprzewodniczący, metropolita poznański abp Jerzy Stroba, sekretarz Episkopatu abp Bronisław Dąbrowski, sekretarz pomocniczy Episkopatu ks. Alojzy Orszulik. Ustalono, że Aleksander Merker i ks. Alojzy Orszulik będą członkami Komisji i zarazem jej sekretarzami.

Na tym posiedzeniu, które trwało także w dniu 21 listopada, strona kościelna postulowała m.in. uchylenie dekretu z 31 grudnia 1956 r. o organizowaniu i obsadzaniu stanowisk kościelnych. Strona kościelna twierdziła, że dekret jest narzędziem walki z Kościołem i utrudnia normalizację stosunków między państwem a Kościołem.

Strona rządowa przyznała, że dekret wymaga zmian, że trzeba znaleźć jakieś wyjście. Postanowiono sprawę powierzyć zespołowi prawnemu. Ustalono, że będzie się nazywał: zespół do spraw legislacyjnych. 
$\mathrm{Na}$ posiedzeniu Komisji w dniu 8 grudnia 1980 r. ustalono, że Sekretariat Episkopatu i Urząd ds. Wyznań uzgodnią skład osobowy zespołu legislacyjnego. Na posiedzeniu 10 stycznia $1981 \mathrm{r}$. zatwierdzono uzgodniony skład. Ze strony rządowej zasiedli w nim: prof. dr Adam Łopatka - dyrektor Instytutu Państwa i Prawa, prof. Michał Pietrzak z Uniwersytetu Warszawskiego, Aleksander Merker - dyrektor w Urzędzie ds. Wyznań, Bogusław Skręta z Urzędu ds. Wyznań, który został sekretarzem zespołu. Stronę kościelną mieli reprezentować: ks. Alojzy Orszulik - sekretarz pomocniczy Episkopatu i członek Komisji Wspólnej, ks. prof. Marian Żurowski SJ z ATK, prof. Andrzej Stelmachowski z Uniwersytetu Warszawskiego, ks. dr Jan Chmiel z Sekretariatu Episkopatu - sekretarz zespołu.

W marcu 1981 r. przewodnictwo zespołu ze strony kościelnej przejął bp Józef Glemp, ordynariusz warmiński, a gdy 7 czerwca 1981 r. został prymasem, arcybiskupem gnieźnieńskim i warszawskim, zastąpił go bp Zygmunt Kamiński, biskup płocki. W ten sposób zespół ze strony kościelnej został powiększony o jednego członka. Po stronie rządowej także zmieniał się skład osobowy zespołu.

Zespół pracował intensywnie. Spotykał się co miesiąc. Dyskusje nie były łatwe, ponieważ członkowie stanęli wobec materii trudnej i nowej. Zespołowi zlecono więcej zadań. Zobowiązano go do wypracowania projektu ustawy o stosunku państwa do Kościoła katolickiego. Mimo napiętej sytuacji w kraju u schyłku1981 r. i wprowadzenia stanu wojennego 13 grudnia prace zespołu nie zostały ani zawieszone, ani zerwane.

Prace nad projektem trwały przeszło trzy lata. Tekst ustawy poprzedzała deklaracja określająca intencje i zasady, którymi kierowano się przy redagowaniu ustawy. Ustawa liczyła 78 artykułów i dzieliła się na 4 działy.

1. Kościół katolicki w Polsce i jego struktura.

2. Działalność Kościoła katolickiego w Polsce i jego organizacje.

3. Sprawy majątkowe.

4. Przepisy przechodnie i końcowe.

Ponadto opracowano statut duszpasterstwa wojskowego i rozporządzenie prezesa Rady Ministrów o wykazach kościelnych osób prawnych.

Uzgodniono uroczyste parafowanie projektów na dzień 14 grudnia 1983 r. w Sekretariacie Episkopatu. Tydzień wcześniej na plenarnym posiedzeniu jeden z członków strony rządowej zawetował przygotowany projekt, składając do protokołu obszerne oświadczenie. Był to Kazimierz Kąkol. Mimo jego nieobecności 14 grudnia 1983 r. dokumenty zostały parafowane w obecności dyrektora Urzędu ds. Wyznań min. prof. Adama Łopatki i sekretarza Episkopatu abp. Bronisława Dąbrowskiego. Parafowany projekt przekazany został na posiedzenie Komisji Wspólnej w dniu 26 marca 1984 r. Przewodniczący strony rządowej Kazimierz Barcikowski oświadczył, że na skutek kontrowersji w zespole rządowym projekt trzeba odłożyć i podziękował zespołowi.

W ciągu następnych lat próbowano nas przekonać do nadania biegu legislacyjnego częściom ustawy. Nie wyraziliśmy zgody i do listopada 1987 r. projekt leżał w szufladzie. W stosunkach państwo-Kościół były różne napięcia, stary aparat partyjny i administracyjny stosował wrogie Kościołowi ustawy i przepisy powielaczowe, mimo że od 
6 lutego 1974 r. był ustanowiony zespół roboczy do kontaktów między rządem a Stolicą Apostolską.

22 lipca 1983 r. zniesiono stan wojenny, sytuacja polityczna w kraju była napięta, a kryzys gospodarczy się pogłębiał. Brakowało artykułów żywnościowych i przemysłowych, także surowców dla fabryk. Sankcje gospodarcze Zachodu dawały się we znaki gospodarce polskiej.

W pierwszych dniach maja i w sierpniu 1987 r. władze szukały pośrednictwa w nawiązaniu kontaktu z opozycją. Prosiły o pomoc przedstawicieli Kościoła, zarówno świeckich, jak i duchownych.

W roku 1987 przewidziana była pielgrzymka Jana Pawła II do Polski w związku z krajowym Kongresem Eucharystycznym. W pierwszych dniach stycznia 1987 r. szef Biura Ochrony Rządu gen. Olgierd Darżynkiwicz odbył rozmowę w Watykanie z o. Robertem Tuccim. Generał BOR tłumaczył, że wizyta papieska nie jest możliwa, ponieważ nie ma środków transportu, zwłaszcza helikopterów, które są przestarzałe i niebezpieczne, a wojskowe są uzbrojone. Na zaproszenie o. Tucciego brałem udział w tych rozmowach. Wobec impasu rozmów w Watykanie postanowiliśmy wspólnie podjąć rozmowy w Warszawie, dokąd przylecieliśmy samolotem 6 stycznia $1987 \mathrm{r}$. Także te rozmowy nie przyniosły rezultatu - zostały zawieszone.

13 stycznia 1987 r. gen. Wojciech Jaruzelski odbył podróż do Rzymu i z honorami głowy państwa został przyjęty w Watykanie, a papież przyjął go na prywatnej audiencji.

Po powrocie gen. Jaruzelskiego z Rzymu wszystkie trudności zniknęły. Zaczęliśmy rozmowy w Warszawie dotyczące spraw technicznych, terminu, programu obsługi prasowej i innych. Jak sobie przypominam, nie było większych trudności w przygotowaniu programu, choć proponowana trasa mogła być dla władz kontrowersyjna: Szczecin, Gdynia, Gdańsk.

W trzeciej dekadzie kwietnia 1987 r. przybył do Polski ze Stolicy Apostolskiej sekretarz Rady ds. Publicznych Kościoła abp Achille Silvestrini. Odbył rozmowy z min. spraw zagranicznych Tadeuszem Olechowskim, z premierem Zbigniewem Messnerem i gen. Wojciechem Jaruzelskim, przewodniczącym Rady Państwa. Przebiegły one w miłej atmosferze, ale nie przyniosły konkretnych rezultatów.

25 kwietnia 1987 r. abp Achille Silvestrini wziął udział w posiedzeniu Rady Głównej Episkopatu w Poznaniu w rezydencji arcybiskupa poznańskiego. Abp Silvestrini najpierw zrelacjonował przebieg rozmów z przedstawicielami władz, następnie - niewątpliwie z mandatu papieża - oznajmił potrzebę powołania Komisji Mieszanej złożonej z przedstawicieli Stolicy Apostolskiej i Episkopatu. Komisja miała przedyskutować, jakie są możliwości bic et nunc nawiązania stosunków dyplomatycznych między PRL a Stolicą Apostolską. Rada Główna inicjatywę przyjęła. Ustalono, że Episkopat Polski będą reprezentować: metropolita poznański abp Jerzy Stroba, sekretarz Episkopatu abp Bronisław Dąbrowski, zastępcy sekretarza Episkopatu - bp Jerzy Dąbrowski i ks. Alojzy Orszulik. Abp Silvestrini podał skład przedstawicieli Rady ds. Publicznych Kościoła, a mianowicie: abp Achille Silvestrini, abp Francesco Colasuonno, mons. Faustino Sainz Muñoz, mons. Janusz Bolonek. Na pierwsze posiedzenie zebrania Komisji wyznaczono 
termin 8-11 maja 1987 r. w Watykanie. Abp Silvestrini nakreślił wówczas wstępne prace Komisji, a mianowicie:

- określenie charakteru nuncjatury w odniesieniu do historii;

- sposób utrzymania tego charakteru nuncjatury w szczególnej sytuacji aktualnego reżimu;

- relacje nuncjatury z Episkopatem;

- sformułowanie tekstu porozumienia Stolica Apostolska-PRL dla odbudowania wzajemnej relacji;

- wyjaśnienie polskiej i międzynarodowej opinii publicznej znaczenia nawiązania stosunków między Stolicą Apostolską a rządem PRL.

Po przedstawieniu tych punktów abp Silvestrini opuścił zebranie. Rada Główna podjęła dyskusję nad jego przedłożeniami. Podsumował ją ks. prymas Józef Glemp:

- Komisja ma za zadnie opracować historię nuncjatury w Polsce;

- w oparciu o historię wykazać społeczeństwu, że nuncjusz jest przedstawicielem Ojca Świętego wobec narodu;

- nuncjusz jedynie formalnie jest akredytowany przy rządzie w celach porozumiewania się z władzą, która z innych niż Kościół tytułów posiada uprawnienia nad społeczeństwem;

- społeczeństwo żąda, żeby Kościół stawał w jego obronie, dlatego powinno aprobować obecność nuncjusza w Polsce;

- należy wypracować kościelną i duszpasterską treść stosunków dyplomatycznych (czego Ojciec Święty oczekuje od nuncjusza);

- nuncjusz musi rozeznać, czy sytuacja i opinia publiczna pozwalają na stosunki dyplomatyczne (Kościół nie może ignorować opinii społecznej);

- trzeba rozstrzygnąć, na jakiej podstawie podjąć stosunki dyplomatyczne: porozumienie?, modus vivendi?, simpliciter przedstawicielstwo?;

- należy wziąć pod uwagę, że konkordat zerwał rząd, i rozstrzygnąć, jakie konsekwencje płyną z tego faktu przy aktualnych stosunkach;

- zdecydować, czy i jak należałoby poinformować społeczeństwo o zamierzeniach Stolicy Apostolskiej;

- pożyteczne byłoby przestudiowanie wypracowanego przez zespół rządowo-kościelny projektu ustawy o stosunku państwa do Kościoła katolickiego w Polsce z dnia 14 grudnia 1983 r.

5 maja 1987 r. w Sekretariacie Episkopatu odbyła się narada zespołu ekspertów, którzy rozważali, jaką formę powinno przyjąć nawiązanie stosunków dyplomatycznych między Stolicą Apostolską a PRL. Rozważano kilka form, a mianowicie: konkordat, konwencję, protokól, modus vivendi, komunikat.

W dyskusji przeważała forma konkordatu, ale zwracano uwagę, że rząd może jej nie przyjąć. Konkordat to najbardziej uroczysta forma umowy międzynarodowej. Zakłada ustanowienie nuncjusza, który w Polsce nie mógłby być dziekanem Korpusu Dyplomatycznego. W latach 70. Stanisław Kania, najbliższy współpracownik Edwarda Gierka, oświadczył nam, że rządowi wystarczy kanonik laterański. 
W wyniku dyskusji opowiedzieliśmy się za konwencją, która ma charakter umowy międzynarodowej podlegającej ratyfikacji, a inne formy odrzuciliśmy. Wysunięto także postulat, aby z konwencją związać ustawę o stosunku państwa do Kościoła katolickiego. Chodziło o to, aby ustawa wynegocjowana z Episkopatem nie mogła być zmieniona bez uzgodnienia ze Stolicą Apostolską.

W dniach 8-11 maja 1987 r. odbyło się w Watykanie pierwsze posiedzenie Komisji Mieszanej w uzgodnionym składzie.

Dyskusja koncentrowała się wokół punktów przedstawionych przez abp. Achille Silvestriniego na posiedzeniu Rady Głównej w dniu 25 kwietnia 1987 r. w Poznaniu. Nie uzgodniliśmy, jaką formę ma mieć umowa między Stolicą Apostolską a PRL w sprawie nawiązania stosunków dyplomatycznych.

Bp Jerzy Dąbrowski otrzymał polecenie przygotowania instrumentum laboris na kolejne posiedzenie Komisji w lipcu $1987 \mathrm{r}$.

8 czerwca 1987 r. przybył do Polski z siedmiodniową pasterską wizytą Ojciec Święty Jan Paweł II. W ostatnim dniu wizyty, w niedzielę 14 czerwca, spotkał się z biskupami w Sekretariacie Episkopatu i wygłosił do nich obszerne przemówienie, w którym m.in. nawiązał do sprawy przywrócenia stosunków dyplomatycznych pomiędzy Stolicą Apostolską a PRL. Powiedział wtedy: W ostatnich latach wtadze Polskiej Rzeczypospolitej Ludowej wystapity z propozycja nawiazania formalnych stosunków dyplomatycznych ze Stolica Apostolską. Ponieważ Episkopat Polski w odnośnej sprawie wypowiedziat się w sensie pozytywnym, musimy sobie wspólnie uświadomić kilka okoliczności, jakie w tym wypadku winny być wzięte pod uwagę. 1) Stosunki pomiędzy stolica Apostolska a Polska maja dtuga historię. Chodzi tutaj o jedna z najstarszych nuncjatur (jak mawiat śp. Kardynat Stefan Wyszyński, tzw. nuncjaturęierwszej klasy). 2) Stosunki maja charakter międzynarodowy, natomiast nie międzypaństwowy. Podmiotem nie jest tu Państwo Watykanskie, ale Stolica Apostolska. Odpowiada to zarazem catoksztattowi tejpostugi, jaka Biskup Rzymu spetnia względem wszystkich Kościotów lokalnych. Chodzi więc także o umocnienie więzi z Episkopatem kraju, z którym stosunki takie zostaja zawierane. 3) W wypadku spoteczeństwa takiego jak Polska, gdzie katolicy stanowiq wiadoma więsszość obywateli, uwydatnia się przez te stosunki jeszcze bardziej więź z Narodem. Doświadczenia minionych wieków (nawet jeśli byty to doraźnie doświadczenia bolesne) dogtębnie potwierdzity tę zasadę. W wypadku tak zwanego kraju "katolickiego” Stolica Apostolska uważa stosunki z odnośnym państwem za rzecz normalna i prawidtowa. Brak tych stosunków jest raczej czymśanormalnym, nawet z punktu widzenia międzynarodowej pozycji danego państwa, a przede wszystkim danego narodu. Może być pewnego rodzaju „krzywda" dla tego narodu.

W dwa tygodnie po wizycie papieskiej w Polsce, 26 czerwca 1987 r. spotkałem się w Sejmie z sekretarzem PRON Stanisławem Cioskiem w sprawie rejestracji „Fundacji Wodnej”. Przy tej okazji Stanisław Ciosek poruszył problem nawiązania stosunków dyplomatycznych między PRL a Stolicą Apostolską. Oświadczył, że rząd polski ma polityczną wolę normalizacji stosunków z Kościołem, a także nawiązania stosunków dyplomatycznych ze Stolicą Apostolską. 
Zrelacjonowałem treść tej rozmowy ks. abp. Bronisławowi Dąbrowskiemu, który zaaranżował spotkanie w Sekretariacie Episkopatu 30 czerwca 1987 r. z Kazimierzem Barcikowskim i Stanisławem Cioskiem. Abp Dąbrowski poinformował, że 6 lipca 1987 r. delegacja Episkopatu udaje się do Rzymu na posiedzenie Komisji Mieszanej. Abp Bronisław Dąbrowski nawiązał do wypowiedzi Ojca Świętego Jana Pawła II z dnia 14 czerwca 1987 r. i do stanowiska Episkopatu wyrażonego w komunikatach z zebrań plenarnych. Oświadczył, że Kościół wyraża wolę wznowienia stosunków dyplomatycznych między Stolicą Apostolską a PRL. Brak tych stosunków nie jest czymś normalnym - jak powiedział Ojciec Święty.

Ksiądz Orszulik przedstawił koncepcję regulacji prawnych na szczeblu PRL-Stolica Apostolska i rząd-Episkopat. Podstawą do nawiązania stosunków dyplomatycznych winna być umowa o charakterze prawa międzynarodowego, która mogłaby się nazywać konwencją. Byłaby ratyfikowana przez Radę Państwa. Stosunki między rządem a Episkopatem winna regulować ustawa o stosunku państwa do Kościoła wynegocjowana w zespole legislacyjnym z mandatu Komisji Wspólnej. Ustawa winna być zakotwiczona w konwencji.

W konwencji powinny być zawarte causae maiores, czyli zastrzeżone Stolicy Apostolskiej, natomiast ustawa powinna regulować tzw. causae minores, a więc problemy z zakresu stosunków Kościól-państwo na wzór wypracowanego projektu ustawy z 1983 r.

Kazimierz Barcikowski powtórzył za Stanisławem Cioskiem, że istnieje polityczna wola rządu nawiązania stosunków dyplomatycznych ze Stolicą Apostolską. Wyraził zadowolenie z pozytywnego podejścia do tej sprawy ze strony kościelnej. Kazimierz Barcikowski postawił pytanie: w jakiej randze mógłby być przedstawiciel Stolicy Apostolskiej - nuncjusza czy pronuncjusza? Rząd chętnie przyjąłby nuncjusza, gdyby nie był dziekanem Korpusu Dyplomatycznego. Przyznał, że konwencja winna być aktem o walorze prawa międzynarodowego. Zapytał też, jak sobie wyobrażamy regulacje wewnętrzne. Oświadczył, że rząd nie chce podejmować rozmów ze Stolicą Apostolską za plecami Episkopatu czy bez jego udziału. W wypracowanie konwencji w ramach Komisji Wspólnej rząd włączy przedstawiciela MSZ. Kazimierz Barcikowski tak podsumował nasze rozmowy:

Chcemy wspólnie dążyć do nawiązania stosunków dyplomatycznych bez zbytniego pośpiechu, ale też $i$ bez odktadania sprawy.

Przyjmujemy, że podstawa nawiazania stosunków dyplomatycznych mogtaby być konwencja - umowa dwustronna o charakterze prawa międzynarodowego, ratyfikowana przez Radę Państwa. Treścia tej umowy bytyby sprawy przeznaczone bezpośrednio kompetencji Stolicy Apostolskiej, przy czym należy mieć na uwadze, że Stolica Apostolska nie może ingerować w wewnętrzne sprawy Polski. Może się tu ukazać cienka granica. Pod pojeciem państwa socjalistycznego - jak mówił - nie należy rozumiećpaństwa ateistycznego. Gdy idzie o inne sprawy z zakresu wewnętrznych stosunków państwo-Kościót, to zostatyby one uregulowane na drodze ustawy, wypracowanej przez Zespót Legislacyjny, a zatwierdzony przez Komisję Wspólną. 
Gdy idzie o rangę delegata Stolicy Apostolskiej, to decyzjez zostawiamy stronie kościelnej, czy będzie to nuncjusz, czy pronuncjusz.

$O$ treści tego spotkania zostanie poinformowany gen. Wojciech Jaruzelski $w$ dniu 3 lipca br.

Kazimierz Barcikowski dodał, że jest przekonany, iż gen. Jaruzelski przyjmie te rozwiązania, co najwyżej doda własne uzupełnienia.

W dniach od 7-9 lipca 1987 r. odbyło się w Watykanie posiedzenie Komisji Mieszanej. Zrelacjonowaliśmy treść rozmowy z Kazimierzem Barcikowskim i Stanisławem Cioskiem z dnia 30 czerwca 1987 r. Wyjaśniliśmy koncepcje regulacji stosunków PRL-Stolica Apostolska, a także regulacje wewnętrzne: rząd-Episkopat. Wyliczyliśmy, jakie sprawy powinny być zawarte w konwencji jako causae maiores, a jakie w ustawie jako causae minores. Przedstawiciele Stolicy Apostolskiej po wyjaśnieniu przyjęli tę dwupoziomową regulację i sporządziliśmy elenchus causae maiores i causae minores.

1 lipca 1987 r. min. Jerzy Kuberski zapytał abp. Achille Silvestriniego, czy byłoby możliwe opracowanie projektu dotyczącego zagadnień, które należałoby rozwiązać w związku z pełną normalizacją stosunków między państwem a Kościołem oraz między Stolicą Apostolską a PRL. Abp Achille Silvestrini powiedział, że może mu dać odpowiedź po posiedzeniu Komisji Mieszanej.

30 lipca 1987 r. spotkał się z min. Jerzym Kuberskim i przekazał mu rozwiązanie dwóch typów kwestii wniesionych na posiedzeniu Komisji Mieszanej: causae maiores, które dotyczą praw Kościoła, i causae minores, a więc kwestii praktycznych. Powiedział, że podane są jedynie przykładowo prawa i wolność Kościoła. Komisja Mieszana podała następujące kwestie, które powinny być ujęte w umowie przed nawiązaniem stosunków dyplomatycznych. Przykładowo wyliczono causae maiores. W Polsce w odniesieniu do Kościoła katolickiego uznawane są:

- prawo rządzenia się i działania zgodnie z jego misją i przepisami prawa kanonicznego;

- swobodne kontaktowanie się ze Stolicą Świętą i z jej przedstawicielem, a także z innymi Kościołami lokalnymi;

- istnienie i swobodne wykonywanie obrządków;

- kompetencja jedyna i wyłączna Stolicy Świętej erygowania, znoszenia i dokonywania zmian Kościołów partykularnych i prowincji kościelnych (KPK, kan. $368,373,431 \$ 3$ i 433$)$;

- kompetencja jedyna i wyłączna Najwyższego Pasterza mianowania biskupów (kan. 377§1), a także, gdy zachodzi potrzeba, ordynariuszy bez sakry biskupiej;

- prawo Kościoła do zakładania i kierowania uniwersytetami (kan. 807), akademiami i wydziałami kościelnymi; konieczność uznania przez prawo państwowe wymienionych instytutów na prawie papieskim działających w Polsce oraz uznania stopni akademickich nadanych studentom duchownym, zakonnym i świeckim;

- prawo własne i wyłączne Kościoła do formacji kandydatów do kapłaństwa przez zakładanie seminariów i kierowanie nimi, według norm zatwierdzonych 
przez Stolicę Świętą odnośnie do wychowania, przygotowania intelektualnego i kościelnego;

- prawo drukowania i rozpowszechniania Pisma Świętego i wyłączne prawo drukowania i rozpowszechniania ksiąg liturgicznych zatwierdzonych przez kompetentną władzę kościelną;

- obowiązek własny i poważny Kościoła troszczenia się o katechizację ludu chrześcijańskiego (dzieci, młodzież i dorośli, por. kan. 773), zgodnie ze wskazaniami wydanymi przez Stolicę Świętą;

- prawo należące do misji Kościoła, aby rozwijać i organizować własne instytucje dobroczynne i opieki społecznej przy współpracy duchowieństwa i świeckich;

- prawo do budzenia powołań misyjnych i popierania inicjatyw zmierzających do ich formacji, wysyłania personelu i pomocy, także finansowej, misjom zagranicznym;

- prawo Kościoła do zakładania, kierowania, odnowy lub znoszenia instytutów życia konsekrowanego (zakony, zgromadzenia, instytuty świeckie) i stowarzyszeń życia apostolskiego;

- prawo do zakładania stowarzyszeń wiernych świeckich dla pełnienia dzieł pobożności i miłosierdzia, dla ożywienia duchem chrześcijańskim porządku doczesnego (kan. $304 \$ 1)$.

Ponadto Stolica Święta jest żywo zainteresowana, aby następujące kwestie (tzw. causa minores), zasadniczo omówione i częściowo rozwiązane przez Komisję Wspólną Rządu i Episkopatu, zostały rozstrzygnięte w sposób zadowalający i w terminie możliwie krótkim:

- swobodna działalność wydawnicza i poligraficzna;

- budownictwo sakralne i kościelne;

- szkoły katolickie;

- pielgrzymki, procesje i nabożeństwa poza terenem kościelnym;

- duszpasterstwo w domach opieki, w zakładach karnych i dla wojskowych;

- dostęp do środków społecznego przekazu;

- ubezpieczenie duchownych;

- nabywanie, zarządzanie i sprzedaż nieruchomości;

- zwolnienie od opłat i podatków od ofiar na cele kultu i Kościoła oraz od dochodów jednostek kościelnych przeznaczonych wyłącznie na cele religijne, charytatywne i wychowawcze.

To wyliczenie, ograniczone do problemów palących, nie wykluczało innych kwestii, których rozwiązaniem miała zająć się Komisja Wspólna Rządu i Episkopatu w duchu szczerej współpracy.

W dniu 18 września 1987 r. na prośbę strony rządowej odbyło się spotkanie w Belwederze w składzie: Kazimierz Barcikowski, Stanisław Ciosek, abp Bronisław Dąbrowski i ks. Alojzy Orszulik.

Kazimierz Barcikowski prosił o uchylenie rąbka tajemnicy, co ustaliła Komisja Wspólna w lipcu w Watykanie. Min. Jerzy Kuberski tylko ogólnie zrelacjonował rozmowę z abp. Achille Silvestrinim z dnia 30 lipca 1987 r. 
Przedstawiliśmy przebieg dyskusji i przykładowe zestawienie tematów do causae maiores i causae minores. Kazimierz Barcikowski powiedział, że projekt ustawy z 14 grudnia 1983 r. może stanowić podstawę do dyskusji nad ustawą o stosunku państwa do Kościoła zawierającącausae minores. Strona rządowa chciała się zapoznać z naszymi ustaleniami na posiedzeniu Komisji Wspólnej w dniu 21 września 1987 r. Podkreśliliśmy, że causae maiores powinny być zawarte w konwencji.

21 września 1987 r. odbyło się posiedzenie Komisji Wspólnej, zrelacjonowaliśmy przebieg rozmów Komisji Mieszanej w lipcu 1987 r. i ustalenia, jakie kwestie przed nawiązaniem stosunków dyplomatycznych powinny być ujęte w konwencji - causae maiores, a jakie w ustawie o stosunku państwa do Kościoła katolickiego - causae minores. Wręczyliśmy stronie rządowej pełny tekst, jaki otrzymał min. Jerzy Kuberski 30 lipca 1987 r. od abp. Silvestriniego.

Kazimierz Barcikowski powiedział, że niektóre sformułowania są zbyt kategoryczne, np. sprawa wyłącznej kompetencji papieża w nominacji biskupów. Erekcja nowych diecezji i parafii też nie może być obojętna dla państwa. Dodał, że trzeba będzie szukać rozwiązań, które będą elastyczne.

Kazimierz Barcikowski postulował, by przed wyjazdem delegacji Episkopatu do Rzymu odbyło się posiedzenie Komisji Wspólnej, żeby rząd mógł sprecyzować swoje stanowisko. Ustalono termin posiedzenia na dzień 9 października 1987 r. Wcześniej zebrało się Biuro Polityczne. Barcikowski powiedział, że należałoby już powołać Zespół Redakcyjny, dodając, iż ze strony rządowej wytworzyliby go: min. Władysław Loranc, prof. Adam Łopatka, wicemin. spraw zagranicznych Tadeusz Olechowski, dyrektor Aleksander Merker, Krzysztof Poźniak z Urzędu ds. Wyznań. Powiedzieliśmy, że skład z naszej strony podamy w późniejszym terminie. Poinformowaliśmy, że następne posiedzenie Komisji Mieszanej odbędzie się w Watykanie w dniach 13-15 października $1987 \mathrm{r}$.

9 października 1987 r. na początku posiedzenia Komisji Wspólnej Kazimierz Barcikowski oświadczył, że koncepcja regulacji stosunków PRL-Stolica Apostolska i rząd-Episkopat została zaprezentowana na posiedzeniu Biura Politycznego KC PZPR. Barcikowski powiedział: Otrzymaliśmy mandat do prowadzenia dalszych rozmów oraz przygotowania stosownych dokumentów. Jeśli chodzi o forme dokumentów, to można przyjąć, że pracujemy nad konwencją PRL-Stolica Apostolska jako aktem międzynarodowym oraz nad ustawą, która będzie regulować stosunki wewnętrzne. Zaznaczył też, że rząd będzie przywiązywał najwyższą wagę do następujących spraw:

- jednoznaczne uznanie przez Kościół Polskiej Rzeczpospolitej Ludowej i jej fundamentalnych praw;

- prawne zagwarantowanie swobody sumienia i swobody praktyk religijnych;

- świeckość państwa i jego instytucji;

- udział władz państwowych w powoływaniu biskupów oraz zmianach diecezji (nie chodzi o sztuczne reguły uciążliwe dla Kościoła, ale o warunki obecności państwa w procesie tych decyzji, a także później, jeśli okazałoby się, że biskup postępuje niewłaściwie - Trzeba poszukać rozwiązań. Nie dyktujemy ich - mówit); 
- szkolnictwo kościelne - równe prawa, a więc równe obowiązki, w tym młodzieży (Szukajmy rozwiązań, bez tworzenia nadmiernych przywilejów, które wywotuja niezadowolenie spoteczne).

W dalszym toku rozmów min. Władysław Loranc opowiedział się za tym, by zespół redakcyjny pracował jednocześnie nad konwencją i ustawą. Potwierdził to Kazimierz Barcikowski. Abp Bronisław Dąbrowski powiedział, że musimy przedstawić Stolicy Apostolskiej ostateczną materię do konwencji i ustawy. Kazimierz Barcikowski dodał, że do ustawy trzeba przejąć prawo „powielaczowe”, które się sprawdziło. Do zespołu trzeba będzie dobrać ekspertów świeckich. Po powrocie z Rzymu trzeba będzie zwołać Komisję Wspólną. Konwencja powinna być gotowa na 10 rocznicę pontyfikatu papieża Jana Pawła II.

Strona kościelna podała skład członków Zespołu Redakcyjnego: abp Jerzy Stroba, metropolita poznański, rektor Katolickiego Uniwersytetu Lubelskiego ks. bp prof. Piotr Hemperek, ks. Alojzy Orszulik i ks. prof. Marian Żurowski z ATK.

PraceZespołu Redakcyjnego rozpoczęły się 4 listopada $1987 \mathrm{r}$. Współprzewodniczyli im: min. Władysław Loranc i abp Jerzy Stroba. Postanowiono powołać ekspertów z zakresu prawa międzynarodowego, państwowego i administracyjnego oraz prawa cywilnego. Ustalono, że Zespół Redakcyjny będzie pracował nad projektem konwencji. Wyniki prac będzie przedstawiał na posiedzeniu Komisji Wspólnej. Do opracowania projektu ustawy o stosunku państwa do Kościoła katolickiego powołano sześć podzespołów, które powinny korzystać z projektu ustawy z 14 grudnia 1983 r. Także do konwencji będą przejęte niektóre artykuły z tegoż projektu. Podzespoły miały swoich współprzewodniczących. Wypracowane projekty przekazywano Zespołowi Redakcyjnemu.

Uzgodniono, że konwencja powinna być opracowana na podstawie zasad przedstawionych Komisji Wspólnej na posiedzeniach 21 września i 9 października 1987 r. Stolica Apostolska wyłączyła spod obrad Zespołu dwa tematy, a mianowicie: nominacje biskupów i tworzenie diecezji. Konwencja po ratyfikacji przez Radę Państwa wejdzie w obrót prawa wewnętrznego. Wyjaśniono, że oprócz wymienionych dwóch tematów Stolica Apostolska wyraziła zgodę na przygotowanie projektu konwencji.

Gotowy tekst konwencji zostanie przekazany przedstawicielom Stolicy Apostolskiej w Komisji Mieszanej. Prace nad konwencją posuwały się szybko. 4 maja 1988 r. tekst konwencji został przyjęty przez Komisję Wspólną, a w czerwcu 1988 r. został przekazany przez przedstawicieli Episkopatu przewodniczącemu delegacji Stolicy Apostolskiej w Komisji Mieszanej. Projekt konwencji składał się z dwudziestu trzech artykułów, przy czym art. 9 i 10 zostały pozostawione do negocjacji ze Stolicą Apostolską. Przed zakończeniem rozmów na temat konwencji Stolica Apostolska postulowała, aby słowo „konwencja” zastąpić słowem „umowa”. Wyrażono przekonanie, że zakończenie prac Komisji Wspólnej nad projektem konwencji i kontynuowanie prac nad projektem ustawy o stosunku państwa do Kościoła umożliwi rozpoczęcie rozmów pomiędzy PRL a Stolicą Apostolską.

Z datą 11 lutego 1989 r. papież Jan Paweł II skierował do ks. prymasa kard. Józefa Glempa pismo informujące, że Stolica Apostolska jest gotowa skierować do Warszawy swego przedstawiciela $\mathrm{w}$ odpowiednim charakterze dla ostatecznego dopracowania 
tekstu konwencji, która jest doniostym dokumentem o charakterze międzynarodowym, będzie mogto dokonać się przy udziale przedstawiciela Stolicy Apostolskiej stale przebywającego w Polsce. Ojciec Święty podkreślał, że nad projektem takiej konwencji pracowaty specjalne Komisje ztożone z przedstawicieli Stolicy Apostolskiej, Episkopatu Polski i wtadz Polskiej Rzeczypospolitej Ludowej.

Myślę, że z uwagi na dokonujące się przemiany polityczne papież nie wysłał do Warszawy stałego przedstawiciela Stolicy Apostolskiej, czekając na dalszy bieg wydarzeń i zmiany ustrojowe w Polsce.

Prace nad projektem ustawy o stosunku państwa do Kościoła trwały o rok dłużej. Do 10 października 1988 r. zespół odbył dwadzieścia siedem posiedzeń, a w podzespołach pracowało trzydziestu dwóch ekspertów. Materia ustawy była obszerna. Trzeba było przełamać socjalistyczne zasady.

7 i 8 marca 1989 r. z projektem zapoznała się Konferencja Episkopatu, wniosła szereg poprawek i postulat, aby dzień 15 sierpnia był wolny od pracy. Trzeba było renegocjować tekst, większość poprawek została uwzględniona, łącznie ze świętem 15 sierpnia. Innych świąt, jak Trzech Króli, Wniebowstąpienia i 8 grudnia, nie udało się przywrócić.

Projekt ustawy o stosunku państwa do Kościoła został przyjęty przez Komisję Wspólną 27 kwietnia 1989 r. Kazimierz Barcikowski powiedział, że skoro Stolica Apostolska nie podejmuje rozmów nad konwencją, to niech zostaną uchwalone przez Sejm wynegocjowane przez nas ustawy.

Dwa dni wcześniej dowiedzieliśmy się, że rząd prowadzi równolegle rozmowy z Kościołami zrzeszonymi w Radzie Ekumenicznej Kościołów nad ustawą pt. Gwarancje wolności sumienia i wyznania. Z uwagi na to, że wiele artykułów tego projektu było kontrowersyjnych i niezgodnych z ustawą o stosunku państwa do Kościoła katolickiego zebrała się Rada Główna Episkopatu w Poznaniu. W czasie posiedzenia Komisji Wspólnej 27 kwietnia 1989 r. zgłosiliśmy nasze zastrzeżenia i postulowaliśmy zmianę określonych przepisów.

Ponieważ projekty ustawy o stosunku państwa do Kościoła katolickiego, ustawy o gwarancjach wolności sumienia i wyznania oraz ustawy o ubezpieczeniach społecznych duchownych (projekt równolegle przygotowany z udziałem przedstawicieli strony kościelnej) zostały już skierowane do Sejmu, powołany został czteroosobowy nadzwyczajny zespół do wyjaśnienia podniesionych przez stronę kościelną zastrzeżeń. Szereg przepisów zostało zmienionych. Strona kościelna postulowała wprowadzenie stwierdzenia, że ustawa nie odnosi się do Kościoła katolickiego.

Wszystkie trzy ustawy zostały uchwalone w dniu 17 maja 1989 r. i ogłoszone w Dzienniku Ustaw z datą 23 maja 1989 r. W ten sposób weszły one w życie.

Stolica Apostolska nie podjęła z rządem PRL rozmów nad projektem konwencji. W połowie maja 1989 r. sekretarz stanu kard. Agostino Casaroli zakomunikował stronie Episkopatu w Komisji Mieszanej, że stosunki dyplomatyczne z PRL zostaną nawiązane na podstawie komunikatu, co też nastąpiło 17 lipca 1989 r. Ogłoszony został w Watykanie i w Warszawie następujący komunikat: Stolica Apostolska i Polska Rzeczpospolita Ludowa, biorac pod uwage chlubne, wielowiekowe tradycje więzi istnieja- 
cych między narodem polskim a Stolica Apostolska oraz pragnac rozwijać wzajemnie przyjazne stosunki, postanowity, co następuje: $w$ dniu dzisiejszym zostaja wznowione stosunki dyplomatyczne między Polska i Stolica Apostolska, w randze Nuncjatury Apostolskiej ze strony stolicy Apostolskiej i Ambasady ze strony Polskiej Rzeczypospolitej Ludowej.

26 sierpnia 1989 r. Stolica Apostolska ogłosiła komunikat o ustanowieniu nuncjuszem apostolskim w Polsce ks. prałata Józefa Kowalczyka.

W ten sposób zakończyła się droga do pełnej normalizacji stosunków między Kościołem a państwem. Prace nad konwencją nie były jednak daremne. Wiele sformułowań w niej zawartych zostało wprowadzonych do wypracowanego przez nuncjusza apostolskiego projektu konkordatu.

Bp Alojzy ORSZULIK (ur. 1928) - polski biskup rzymskokatolicki, pallotyn, wieloletni pracownik Sekretariatu Konferencji Episkopatu Polski. W 1951 r. wstąpił do zgromadzenia księży pallotynów, w którym przyjął święcenia kapłańskie w 1957 r. W 1962 r. rozpoczął pracę w Sekretariacie Konferencji Episkopatu Polski, gdzie pracował m.in. w Biurze Prasowym, a także uczestniczył w najważniejszych rozmowach państwo-Kościół. W 1987 r.znalazł sięw składzie Komisji MieszanejStolicy Apostolskiej i Episkopatu Polski ds. nawiązania stosunków dyplomatycznych między Watykanem i Polską. Uczestniczył w rozmowach w Magdalence i w obradach Okrągłego Stołu. W latach 1989-1994 był zastępcą sekretarza Episkopatu Polski. W latach 1989-1992 biskup pomocniczy diecezji siedleckiej, a w latach 1992-2004 pierwszy biskup ordynariusz nowo erygowanej diecezji łowickiej. Obecnie na emeryturze. 